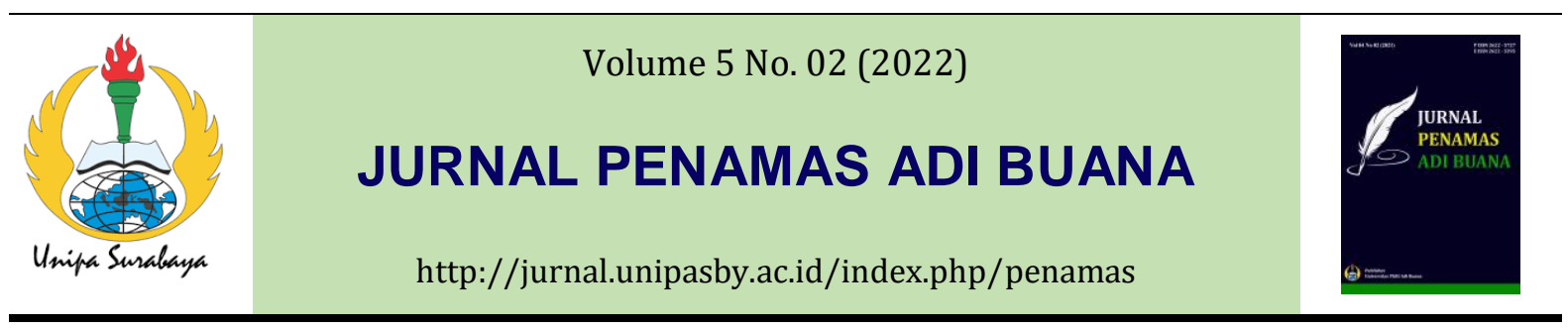

\title{
Surat Daring RT/RW berbasis Physical distancing
}

\author{
Tining Haryanti ${ }^{1 *}$, Indah Kurniawati ${ }^{2}$, Badruli Martati ${ }^{1}$ \\ ${ }^{1}$ Fakultas Teknik, Universitas Muhammadiyah Surabaya, Surabaya, Indonesia, \\ ${ }^{2}$ Fakultas Keguruan Ilmu Pendidikan, Universitas Muhammadiyah Surabaya, Surabaya, Indonesia
}

*Email: tining.haryanti@ft.um-surabaya.ac.id

\section{Informasi Artikel}

Kata kunci:

Surat daring, teknologi, physical distancing

Diterima: 11-06-2021

Disetujui: 20-01-2022

Dipubikasikan: 31-01-

2022

\section{Abstrak}

Dengan berakhirnya PSBB tahap 3 di Surabaya Raya, penambahan jumlah pasien Covid-19 masih belum mengalami penurunan. Hal ini terbukti pada berlebihnya kapasitas Rumah Sakit rujukan Covid-19. Upaya pemerintah dalam pemutusan mata rantai penularan Covid-19 telah dilakukan, baik dari penyuluhan penularan penyakit, kebersihan, hingga penyediaan wastafel pencuci tangan dan penyemprotan disinfektan secara berkala di perumahan, perkampungan dan perkantoran. Peran serta setiap lapisan masyarakat menjadi hal yang sangat berarti dalam penekanan jumlah kasus Covid-19. Jelang penerapan New Normal, protokol Covid-19 tetap harus diterapkan, diantaranya adalah mematuhi physical distancing. Program ini ditujukan untuk mendukung penerapan protokol kesehatan pada kepengurusan surat menyurat pada lingkungan RT dengan mematuhi physical distancing melalui optimalisasi teknologi. Keterlibatan tokoh masyarakat dalam hal ini RT/RW sangat diperlukan. Sudah seharusnya masa pandemic bukan menjadi halangan bagi RT/RW dalam memberikan pelayanan kepada masyarakat termasuk dalam pembuatan surat. Rata - rata pelayanan surat menyurat RT untuk keperluan warga sekecamatan berjumlah lebih dari 2.000 surat per bulan. Keberadaan program ini diharapkan selain dapat mematuhi physical distancing, juga dapat memberikan kemudahan pelayanan surat menyurat baik bagi perangkat RT/RW maupun warga. Sehingga pada akhirnya aktivitas pelayanan surat menyurat RT/RW tetap dapat dilaksanakan meskipun dalam masa pandemic seperti saat ini.

\section{Keywords :}

Online Mail,

Technology, Physical distancing

\section{Abstract}

With the end of Phase 3 of PSBB in Greater Surabaya, the number of Covid19 patients has not decreased. This is evident in the excess capacity of the Covid-19 referral hospital. The government's efforts to break the chain of transmission of Covid-19 have been carried out, both from counseling on disease transmission, hygiene, to providing hand washing sinks and spraying disinfectants regularly in housing, villages and offices. The participation of every level of society is very important in suppressing the number of Covid-19 cases. Ahead of the implementation of the New Normal, the Covid-19 protocol must still be implemented, including complying with physical 
distancing. This program is intended to support the application of health protocols in the management of correspondence in the RT environment by complying with physical distancing through optimizing technology. The involvement of community leaders in this case RT/RW is very necessary. The pandemic period should not be an obstacle for RT/RW in providing services to the community, including in making letters. The average RT correspondence service for the needs of residents in the sub-district amounted to more than 2,000 letters per month. The existence of this program is expected in addition to complying with physical distancing, it can also provide convenience for correspondence services for both RT/RW devices and residents. So that in the end the RT/RW correspondence service activities can still be carried out even during the current pandemic

\section{PENDAHULUAN}

Masa pandemic global corona virus sejak awal 2020 yang belum berakhir hingga saat ini(Djalante et al., 2020), mengharuskan berbagai jenis pekerjaan dan pelayanan beradaptasi dalam menjalankan operasionalnya. Sebagaimana anjuran WHO tentang physical distancing(Bergman et al., 2020), setiap lini pekerjaan diharuskan menerapkan jarak dalam berinteraksi. Teknologi mengambil peranan (Mumm \& Mutlu, 2011) besar dalam membantu pekerjaan untuk tetap dilakukan dengan menjaga physical distancing, seperti daring dalam pembelajaran, meeting daring, seminar daring, pelayanan kesehatan secara daring hingga perdagangan daring. Tanpa adanya adaptasi maka pekerjaan hampir tidak dapat dikerjakan selama masa pandemic(Cucinotta \& Vanelli, 2020). RT/RW menjadi garda terdepan dalam memberikan layanan informasi maupun berinteraksi langsung dengan warga. Pemberian informasi yang akurat tentang kondisi warga hingga bekerjasama dengan warga dalam membangun Kampung Tangguh covid menjadi bukti nyata kontribusi RT/RW dalam penanganan pandemic global ini. Pentingnya peranan RT/RW dalam memonitor warga diwujudkan dalam berbagai aturan pemerintah tentang administrasi kependudukan. Berbagai aktivitas yang berkaitan dengan administrasi kependudukan diwajibkan surat pengantar RT/RW setempat. Misalkan surat pengantar RT/RW untuk kelahiran, Surat Pengantar RT/RW untuk kematian, Surat Pengantar RT RW untuk warga tidak mampu dan lain lain. Peraturan kependudukan tertuang pada berbagai peraturan pemerintah baik daerah maupun nasional. Berdasarkan data bahwa pelayanan warga dalam kebutuhan surat menyurat RT/RW setiap kecamatan di Jawa Timur khususnya cukup tinggi, sejumlah 2.000 pelayanan surat warga per kecamatan per bulan. Untuk tetap dapat melakukan pelayanan surat dengan menerapkan physical distancing diperlukan kemudahan dalam sarana prasarananya. Penggunaan akses surat menyurat secara daring selain dapat menerapkan physical distancing juga memangkas waktu proses layanan. Jumlah RT RW di Surabaya sejumlah 9,271 berdasarkan data dipensukcapil Surabaya http://dispendukcapil.surabaya.go.id/layanan-catatan-sipil/402-jumlah-rtrw-alkmk-se-kota-surabaya-2010-2013. RT/RW dan warga memiliki berbagai ragam latar belakang, baik secara pedidikan maupun perekonomian. Program yang mudah tanpa memerlukan persyaratan yang 
menyulitkan baik secara sarana prasarana maupun skill diperlukan sehingga layanan RT/RW tetap dapat dilaksanakan. Pengadaan Sistem atau program dengan biaya yang mahal dan proses pengerjaan yang panjang tidak menjadi solusi yang tepat ditengah pandemic seperti saat ini. Secara umum surat keterangan yang diterbitkan oleh RT RW setempat untuk menunjang berbagai keperluan adminitrasi kependudukan. Hal ini berdasarkan Peraturan Daerah Kota Surabaya Nomor 6 tahun 2019 pasal 14. Pengabdian ini diterapkan pada RT 30 RW 10 Ds Jumputrejo, Sidoarjo, Jawa Timur. RT 30 memiliki jumlah warga 53KK dengan latar belakang pekerjaan pabrik, serabutan, perkantoran, transportasi, dan mobilitas yang tinggi keluar kota. Adanya PSBB (Putsanra, 2020) mengharuskan warga yang melakukan perjalanan membawa surat pengantar (Humas, 2020) dari RT, namun permasalahan muncul, dimana physical distancing harus dijalankan namun kepengurusan surat menyurat saat ini masih offline (bertemu langsung). Sistem surat daring diperlukan untuk memastikan kegiatan pengajuan surat masyarakat tetap dapat dilaksanakan namun tetap mematuhi protokol kesehatan dengan physical distancing.

\section{METODE}

Surat pengantar RT RW diperlukan warga dalam kepengurusan adminsitrasi public. Berdasarkan wawancara dengan RT 30 maupun masyarakat, Surabaya didapatkan informasi pengajuan surat pengantar. Proses pengajuan surat pengantar RT RW selama ini dilakukan secara manual yaitu warga mendatangi RT/RW setempat dengan membawa KTP dan mengisi buku permintaan surat pengantar dengan menentukan keperuntukan surat. RT/RW memberikan surat pengantar tersebut dan memfotocopy sebagai arsip.

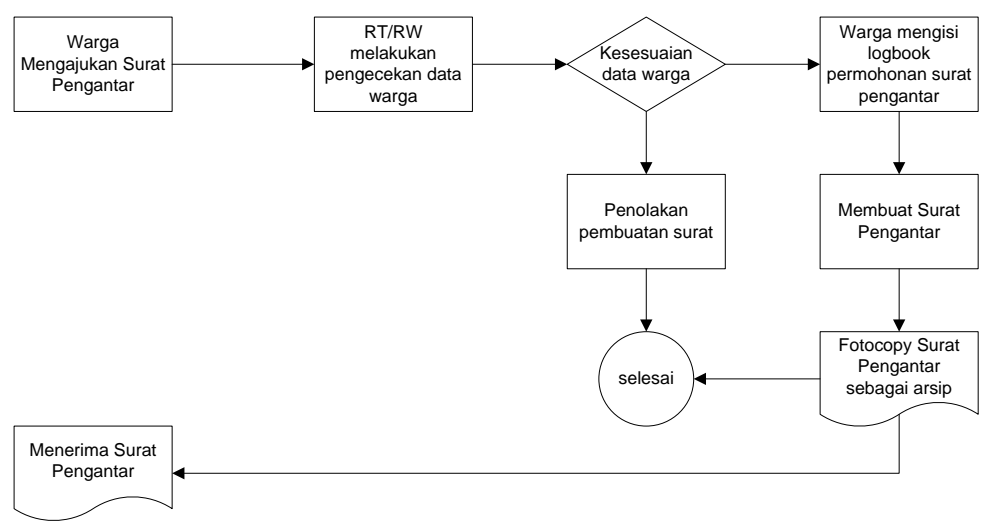

Gambar 1 Proses pengajuan surat saat ini

Berdasarkan alur permohonan surat pengantar RT/RW pada gambar 1 terdapat proses pertemuan secara langsung. Hal ini tidak sesuai dengan prinsip physical distancing. Pengajuan permohonan surat pengantar juga memungkinkan waktu yang diperlukan relatif lama dan kemungkinan adanya kesalahan dalam pengecekan kesesuaian data warga. Pengisian logbook permohonan surat pengantar secara manual menyulitkan pengecekan surat-surat yang pernah dibuat sebelumnya. Fotocopi surat 
sebagai arsip, selain menambah biaya, tidak paperless (Giles, 2012) juga memerlukan tempat fisik penyimpanan. Solusi secara praktis, mudah dan murah yang dapat ditawarkan untuk mengantisipasi permasalahan dan kekurangan yang muncul pada proses pengajuan surat pengantar RT RW adalah dengan pemanfaatan teknologi yang ada yaitu penggunaan pengajuan surat pengantar RT RW secara daring. Kemudahan persyaratan baik keahlian dan sarana prasarana menjadi salah satu alasan pemilihan optimalisasi teknologi pada pengajuan surat pengantar RT RW secara daring. Adapun proses pengajuan surat pengantar RT/RW secara online(gambar 2) dapat digambarkan sebagai berikut

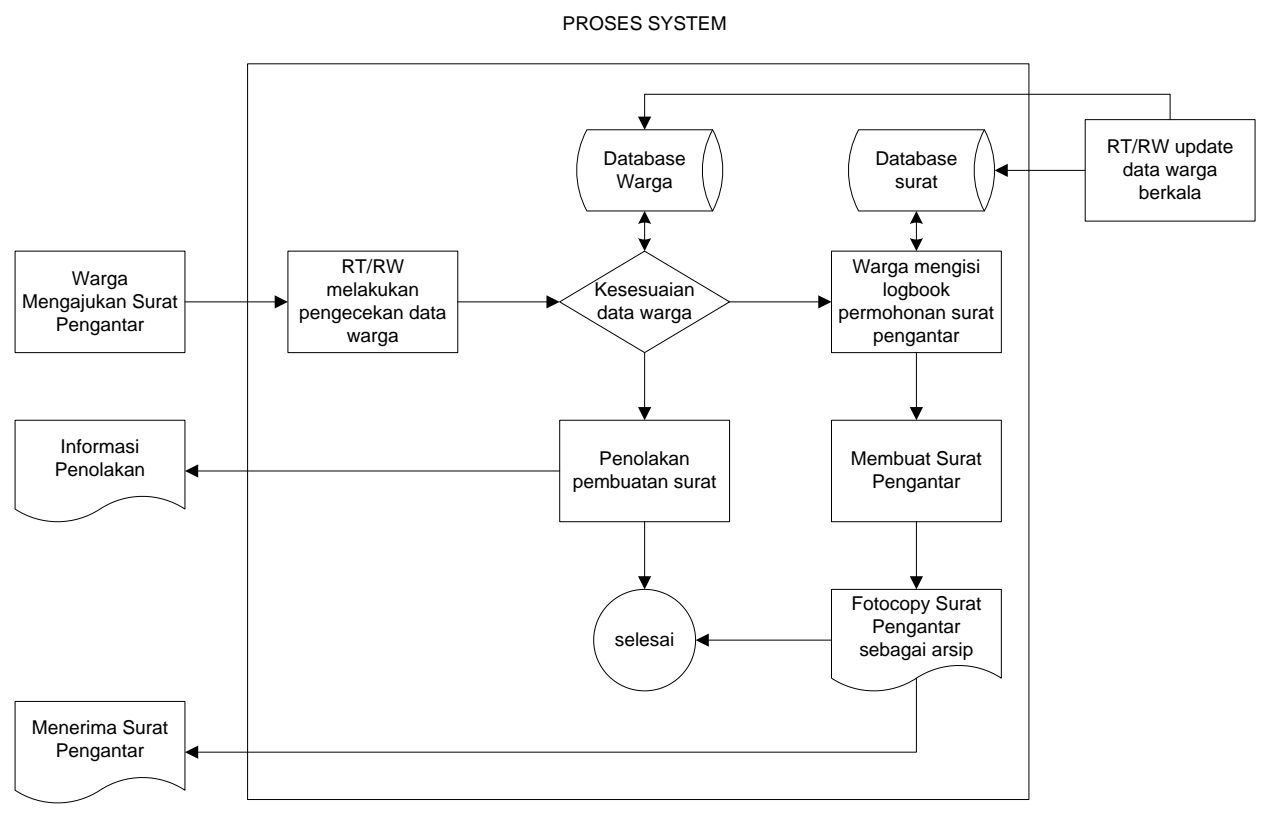

Gambar 2 Proses Pembuatan Surat yang diusulkan

Warga yang akan mengajukan permintaan surat pengantar RT/RW memasukkan data dan keperuntukan surat pada alamat link yang telah disediakan. Sistem akan memproses pengecekan validasi data warga, apabila warga merupakan warga RT/RW tersebut, maka sistem akan memperoses surat yang diperlukan. Sedangkan apabila terdapat ketidak sesuaian data/ ketidak lengkapan data maka sistem akan menolak pengajuan warga. Secara berkala admin atau RT/RW harus melakukan pengecekan terhadap basis data (Haryanti \& Pribadi, 2019) warga, misalkan ada penambahan/ perubahan data warga. Pemilihan user interface yang sederhana diharapkan memudahkan pengguna (Haryanti \& Subriadi, 2020) dalam menggunakan sistem. Adapun luaran sistem berupa Surat pengantar sesuai dengan keperuntukannya dengan format pdf (gambar 3) dan takah sebagai berikut: 


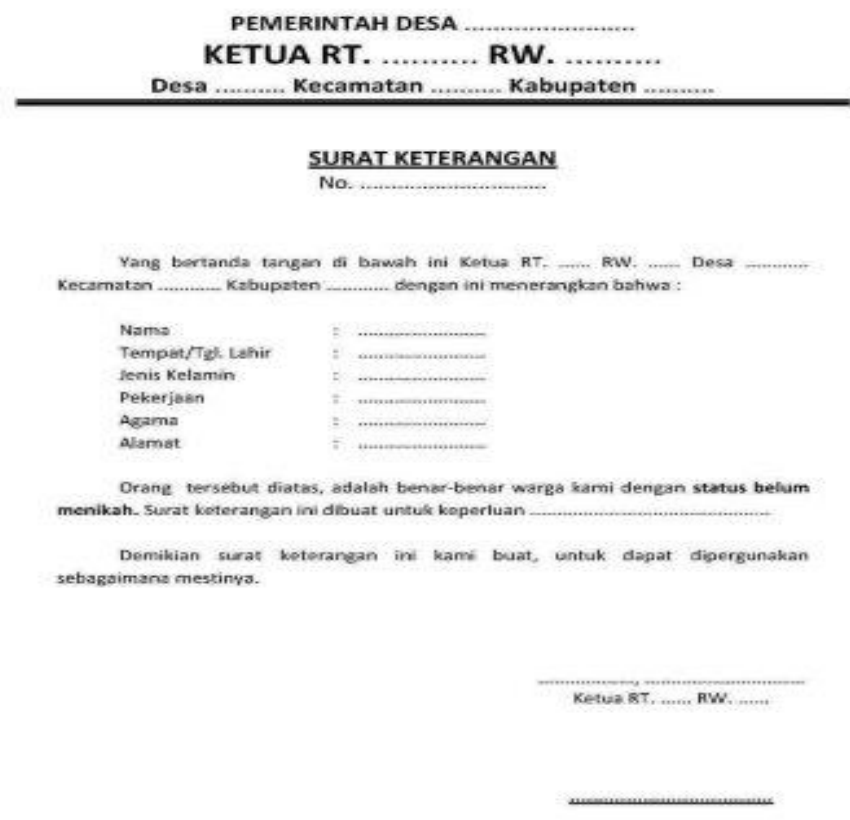

Gambar 3 Surat Keterangan

Surat Pengantar RT berbasis Daring ini dibangun dengan pengoptimalan teknologi yang telah ada sebelumnya, seperti Google form (Iqbal et al., 2018) dan fasilitas pengiriman otomatis ke alamat email (gambar 4). Adapun gambaran IPTEK sistem sebagai berikut: 


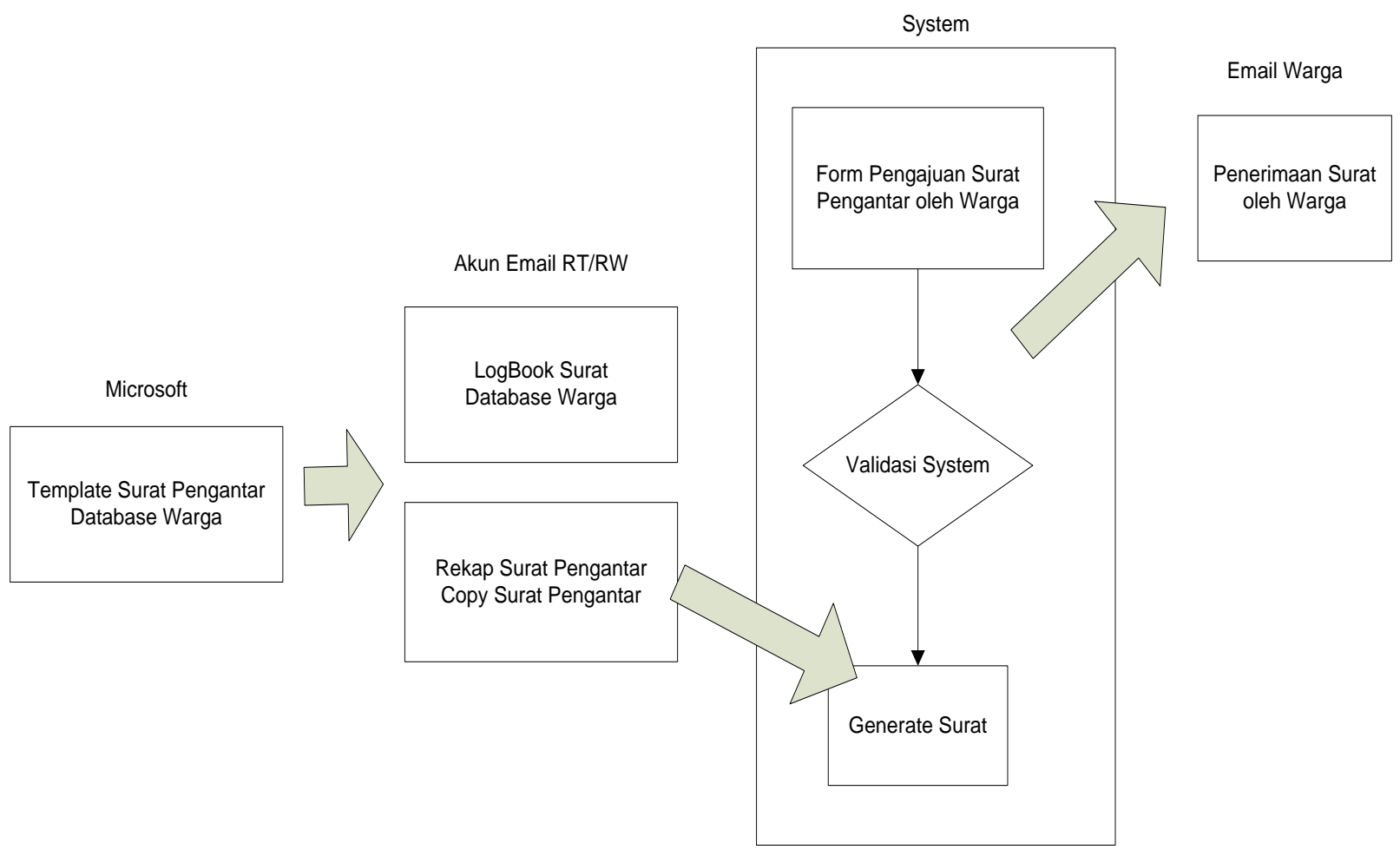

Gambar 4 Gambaran IPTEK surat Daring

Pelaksanaan pendampingan pembuatan surat daring ini melibatkan RT 30 di Kec Sukodono yang berjumlah 53K atau kurang lebih 150penduduk. Pendampingan dilaksanakan selama bulan Juli 2020 (Tabel 1) dengan tahapan pelaksanaan sebagai berikut:

\section{Tabel 1 Metode Pelaksanaan}

\begin{tabular}{|l|l|l|l|l|}
\hline $\begin{array}{l}\text { Pelaksanaan } \\
\text { Program }\end{array}$ & Sasaran & Luaran & $\begin{array}{l}\text { Indikator } \\
\text { Keberhasilan }\end{array}$ & Peran Mitra \\
\hline Tahap Persiapan & \multicolumn{5}{|l|}{} \\
\hline $\begin{array}{l}\text { Pertemuan/ } \\
\text { komunikasi untuk } \\
\text { menyamakan } \\
\text { persepsi } \\
\text { implementasi } \\
\text { kegiatan dengan } \\
\text { tujuan mitra }\end{array}$ & Mitra pengabdian & MoU & $\begin{array}{l}\text { Kesepakatan } \\
\text { program } \\
\text { kerjasama }\end{array}$ & $\begin{array}{l}\text { Mensosialisasikan } \\
\text { pada masyarakat }\end{array}$ \\
\hline $\begin{array}{l}\text { Tahap Implementasi } \\
\text { Pembuatan email } \\
\text { RT/RW dan } \\
\text { setting database } \\
\text { warga }\end{array}$ & Mitra Pengabdian & SOP & $\begin{array}{l}\text { Database } \\
\text { tergenerate 100\% }\end{array}$ & $\begin{array}{l}\text { Memastikan } \\
\text { validitas data }\end{array}$ \\
\hline $\begin{array}{l}\text { Pembuatan } \\
\text { tampilan } \\
\text { pengajuan surat }\end{array}$ & Mitra Pengabdian & SOP & $\begin{array}{l}\text { Kesesuaian } \\
\text { Proses }\end{array}$ & $\begin{array}{l}\text { Pengecekan } \\
\text { kesesuaian proses }\end{array}$ \\
\hline
\end{tabular}




\begin{tabular}{|c|c|c|c|c|}
\hline \multicolumn{5}{|l|}{$\begin{array}{l}\text { pengantar oleh } \\
\text { warga }\end{array}$} \\
\hline Ujicoba Sistem & Mitra Pengabdian & Manual Sistem & $\begin{array}{l}\text { Dapat diakses, } \\
\text { tidak ada error }\end{array}$ & $\begin{array}{l}\text { Mensosialisasikan } \\
\text { pada masyarakat }\end{array}$ \\
\hline $\begin{array}{l}\text { Pembuatan video } \\
\text { tutorial }\end{array}$ & Mitra pengabdian & Video tutorial & Unggah Link & $\begin{array}{l}\text { Mensosialisasikan } \\
\text { pada masyarakat }\end{array}$ \\
\hline \multicolumn{5}{|c|}{ Tahap Monitoring dan Evaluasi } \\
\hline $\begin{array}{l}\text { Monitoring, } \\
\text { evaluasi, } \\
\text { supervisi, dan } \\
\text { rencana tindak } \\
\text { lanjut }\end{array}$ & $\begin{array}{l}\text { Tim Pengusul } \\
\text { dan Mitra } \\
\text { Pengabdian }\end{array}$ & $\begin{array}{l}\text { 1. Dokumen } \\
\text { monitoring } \\
\text { program. } \\
\text { 2. Dokumen } \\
\text { evaluasi } \\
\text { program. } \\
\text { 3. Dokumen } \\
\text { rencana tindak } \\
\text { lanjut. }\end{array}$ & $\begin{array}{l}\text { 1. Monitoring } \\
\text { program. } \\
\text { 2. evaluasi } \\
\text { program. } \\
\text { 3.rencana tindak } \\
\text { lanjut. }\end{array}$ & $\begin{array}{l}\text { Pengisian feedback } \\
\text { melalui google } \\
\text { form }\end{array}$ \\
\hline \multicolumn{5}{|c|}{ Tahap Penyusunan Laporan Pelaksanaan Program } \\
\hline $\begin{array}{l}\text { Penyusunan } \\
\text { laporan } \\
\text { pelaksanaan } \\
\text { program }\end{array}$ & Tim pengusul & Laporan program & $\begin{array}{l}\text { Dokumen laporan } \\
\text { pelaksanaan } \\
\text { program }\end{array}$ & \\
\hline
\end{tabular}

\section{HASIL DAN PEMBAHASAN}

Pengabdian masyarakat pembuatan program Surat Daring berbasis Physical distancing ini menghasilkan kecepatan proses pembuatan surat. Pengajuan surat yang sebelumnya memerlukan waktu 1-3 hari, dengan adanya Sistem surat daring, pembuatan surat dapat dilakukan dengan waktu kurang dari 1 (satu) jam, table 2

Tabel 2 Waktu Pengerjaan Surat

\begin{tabular}{|l|c|l|}
\hline Uraian & Jumlah & Waktu \\
\hline $\begin{array}{l}\text { Pembuatan Surat } \\
\text { dengan pengajuan non } \\
\text { Daring (kondisi } \\
\text { normal) }\end{array}$ & $5 /$ hari & $1-3$ hari \\
\hline $\begin{array}{l}\text { Pembuatan Surat } \\
\text { dengan pengajuan non } \\
\text { Daring (kondisi lock- } \\
\text { down) }\end{array}$ & $1-2$ / hari & \\
\hline $\begin{array}{l}\text { Pembuatan Surat } \\
\text { dengan pengajuan non } \\
\text { Daring }\end{array}$ & $4 /$ hari & kurag dari 1 jam \\
\hline
\end{tabular}


Selain itu, pembuatan surat pengantar yang sebelumnya sempat terhambat karena adanya isolasi mandiri, setelah adanya sistem surat daring, aktivitas pembuatan surat pengantar mulai dapat dilakukan secara normal tanpa adanya interaksi secara langsung.

Respon masyarakat terhadap adanya surat daring positif (table 3) dengan jumlah 70\% masyarakat setuju dan 30\% masyarakat tidak setuju.

Tabel 3 Respon Masyarakat

\begin{tabular}{|l|c|l|}
\hline Respon Masyarakat & Jumlah & Keterangan \\
\hline $\begin{array}{l}\text { Surat Daring } \\
\text { memberikan kemudahan } \\
\text { dalam pengajuan surat } \\
\text { pengantar RT }\end{array}$ & $70 \%$ & Alasan (2 terbanyak) \\
\hline $\begin{array}{l}\text { Surat Daring tidak } \\
\text { memberikan kemudahan } \\
\text { dalam pengajuan surat } \\
\text { pengantar RT }\end{array}$ & $30 \%$ & $\begin{array}{l}\text { 2. Mudah (tidak ribet) } \\
\text { Alasan (2 terbanyak) }\end{array}$ \\
\hline
\end{tabular}

Pembuatan surat keterangan secara manual, selain memerlukan waktu yang relative lama, juga tidak efektif untuk penyimpanan (memerlukan tempat penyimpanan), gambar 5

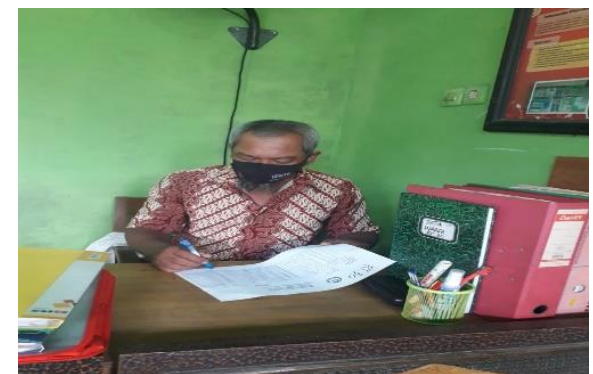

Gambar 5 Pembuatan Surat Pengantar

\section{KESIMPULAN}

Kesimpulan harus mengindikasi secara jelas hasil-hasil yang diperoleh, kelebihan dan kekurangannya, serta kemungkinan pengembangan selanjutnya. Kesimpulan dapat berupa paragraf, namun sebaiknya berbentuk point-point dengan menggunakan numbering atau bullet.

Kesimpulan dalam pengabdian kepada masyarakat tentang Surat Daring berbasisi Physical distancing kepada masyarakat RT 30 Kec Sukodono, Jawa Timur berjalan dengan lancar dalam proses pelaksanaannya selama kurang lebih 1(satu) bulan. Berdasarka hasil angket yang disebarkan ke masyarakat menunjukkan bahwa masyarakat terbantu dengan adanya pembuatan surat menyurat secara daring yang mendukung program pemerintah yaitu physical distancing. Pembuatan surat daring 
ini diharapkan dapat diimplementasikan pada lokasi yang lainnya sehingga penerapan physical distancing dapat dilaksanakan. Kedepannya optimalisasi teknologi ini diharapkan memotong waktu yang relative lama dalam kepengurusan surat menyurat.

\section{UCAPAN TERIMAKASIH}

Ucapan terimakasih atas terselenggaranya pengabdian ini ditujukan pada jajaran pengurus RT $30 \mathrm{Kec}$ Sukodono, Jawa Timur atas kerjasama yang diberikan. Ucapan terimakasih selanjunya ditujukan atas dukungan moril dan materiil oleh Universitas Muhammadiyah Surabaya dan semua pihak sehingga program pengabdian masyarakat terselenggara

\section{DAFTAR PUSTAKA}

Bergman, D., Bethell, C., Gombojav, N., Hassink, S., \& Stange, K. C. (2020). Physical distancing with social connectedness. Annals of Family Medicine. https://doi.org/10.1370/afm.2538

Cucinotta, D., \& Vanelli, M. (2020). WHO declares COVID-19 a pandemic. In Acta Biomedica. https://doi.org/10.23750/abm.v91i1.9397

Djalante, R., Lassa, J., Setiamarga, D., Sudjatma, A., Indrawan, M., Haryanto, B., Mahfud, C., Sinapoy, M. S., Djalante, S., Rafliana, I., Gunawan, L. A., Surtiari, G. A. K., \& Warsilah, H. (2020). Review and analysis of current responses to COVID-19 in Indonesia: Period of January to March 2020. Progress in Disaster Science. https://doi.org/10.1016/j.pdisas.2020.100091

Giles, J. (2012). Going paperless: The digital lab. Nature. https://doi.org/10.1038/481430a

Haryanti, T., \& Pribadi, A. (2019). E-Commerce Service Design Readiness using ITIL framework with IT Balanced Scorecard Objective (Case Study: University ECommerce). Procedia Computer Science, 161, 283-290. https://doi.org/10.1016/j.procs.2019.11.125

Haryanti, T., \& Subriadi, A. P. (2020). Factors and Theories for E-Commerce Adoption: A Literature Review. International Journal of Electronic Commerce Studies, 11(2), 87105. https://doi.org/http://dx.doi.org/10.7903/ijecs.1910

Humas. (2020). Terbitkan SE, Ketua Gugus Tugas Tegaskan Mudik Dilarang dan Tidak Ada Kelonggaran. Setkab.Go.Id.

Iqbal, M., Simarmata, J., Feriyansyah, F., Tambunan, A. R. S., Sihite, O., Gandamana, A., Eza, G. N., Kurniawan, F., Asiah, A., Rozi, F., Faisal, F., Manurung, I. F. U., Ihwani, M., Nathan, P. L. A., Sitanggang, N., Simbolon, N., Simanjuntak, E. B., \& Limbong, T. (2018). Using Google form for student worksheet as learning media. International Journal of Engineering and Technology(UAE). https://doi.org/10.14419/ijet.v7i2.29.13646

Mumm, J., \& Mutlu, B. (2011). Human-robot proxemics: Physical and psychological distancing in human-robot interaction. HRI 2011 - Proceedings of the 6th ACM/IEEE International Conference on Human-Robot Interaction. https://doi.org/10.1145/1957656.1957786 
Putsanra, D. V. (2020). Arti PSBB yang Dibuat untuk Cegah Penyebaran Corona di Indonesia. In Tirto.id. 